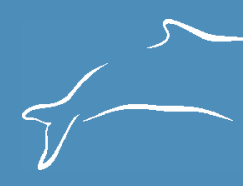

\title{
Observation of a potential mating herd in Amazonian manatee
}

\section{Article Info}

\begin{tabular}{|c|c|}
\hline Manuscript type & Note \\
\hline \multicolumn{2}{|l|}{ Article history } \\
\hline Received & 14 November 2015 \\
\hline Received in revised form & 23 January 2016 \\
\hline Accepted & 23 January 2016 \\
\hline Available online & 30 December 2017 \\
\hline \multicolumn{2}{|c|}{ Responsible Editor: Nataly Castelblanco } \\
\hline \multicolumn{2}{|c|}{$\begin{array}{l}\text { Citation: Carvalho, C., Gräbin, D.M. and Marmontel, M. } \\
\text { (2017) Observation of a potential mating herd in Amazonian } \\
\text { manatee. Latin American Journal of Aquatic Mammals 12(1-2) } \\
\text { 40-44. https://doi.org/10.5597/lajam00239 }\end{array}$} \\
\hline
\end{tabular}

The first reference to 'estrus' in Amazonian manatee (Trichechus inunguis) dates back to 1790 , by Alexandre Rodrigues Ferreira (1903) in his 'Philosophical Travels'. More detailed reports of sexual behavior of the species in Brazil, however, only appeared in Pereira (1944) during his travels through rivers of the Amazon basin. In his account on the Amazonian manatee, the author describes the so called 'cavalgaçáo', 'cavalgaria' or 'vadiação', event in which manatees are found in groups following one or more females.

In Florida manatees (T. manatus latirostris), Hartman (1979) called these associations between a female in estrus and courting males 'estrous herds'. During these reproductive herds males mount and hug the female from the back, and position themselves under her, in order to access her abdomen.

Anderson and Birtles (1978) and Preen (1989) also reported events of reproductive nature in dugongs (Dugong dugon) in Australian bays. The former described a group of dugongs breaking the surface abruptly, followed by exposures of tail and body above the water, and the attempt of one individual to mount another. The latter described a sequence of courting and mating behavior in dugongs, including splashing, following, fighting and mounting. In the case of the Steller sea cow (Hydrodamalis gigas), G.W. Steller (Frost, 1988) described the pursuit of a female by a male, reminiscent of the descriptions of reproductive groups, however involving a single pair (Anderson, 2002; Steller, 2011).

Some of the behaviors cited above for other sirenian species are similar to those observed for Amazonian manatees on 01 June 2015 in the Mamirauá Sustainable Development Reserve, in the mid-Solimóes River area, Brazilian Amazon. The sighting of the presumed group of about five manatees

\section{Camila C. de Carvalho ${ }^{\dagger, *}$, Diogo M. Gräbin ${ }^{\ddagger}$ and Miriam Marmontel}

${ }^{\dagger}$ Research Group on Amazonian Aquatic Mammals, Mamirauá Institute for Sustainable Development, Estrada do Bexiga 2584, 69553-225 Tefé, AM, Brazil

${ }^{*}$ Research Group on Ecology and Conservation of Felids in Amazonia, Mamirauá Institute for Sustainable Development, Estrada do Bexiga 2584 , 69553-225 Tefé, AM, Brazil

*Correspondent author: camila.carvalho@mamiraua.org.br in reproductive behavior took place close to a field base of the Mamirauá Institute for Sustainable Development, in the Mamirauá Lake (02059'06”S, 6454'49”W), a water body located between the floodplains of the Japurá and Solimóes rivers (Figure 1). The lake has an area of $225 \mathrm{~km}^{2}$ and changes seasonally with the annual flooding cycle, presenting a level variation of up to $11 \mathrm{~m}$. Through monitoring studies by radio telemetry of three manatees captured in the Mamirauá Lake, manatees are known to use such aquatic vegetationrich floodplain areas, especially during the high water period (April-June) (Arraut et al., 2010).

Observations of the group were conducted from $06: 00 \mathrm{~h}$ to 06:30h, aboard a wooden canoe, moved by paddle, positioned $10 \mathrm{~m}$ away from the group. All canoe movements were made slowly to avoid perturbation of the water or noises that might startle the animals and cause them to flee. At first approach, the observed group submerged and did not return to the surface immediately. However, after a few minutes, the group reappeared in the same area, engaged in courting behavior. The observations were recorded through photographs and video with a Nikon CoolPix P600 camera. Film was later analyzed to describe the behavior.

The first animal sighted was presumed to be a female, because it was the center of all behaviors observed. Upon first observation the animal remained with the dorsum exposed out of the water, and we could observe the animal breathe and twist its body, apparently in response to some underwater stimulus. In sequence, we saw the pectoral fin of a presumed male on the female's side. At this point, the female again contorted, exposing a large part of her body above the water surface (Figure 2), and submerged afterwards with the presumed males. 


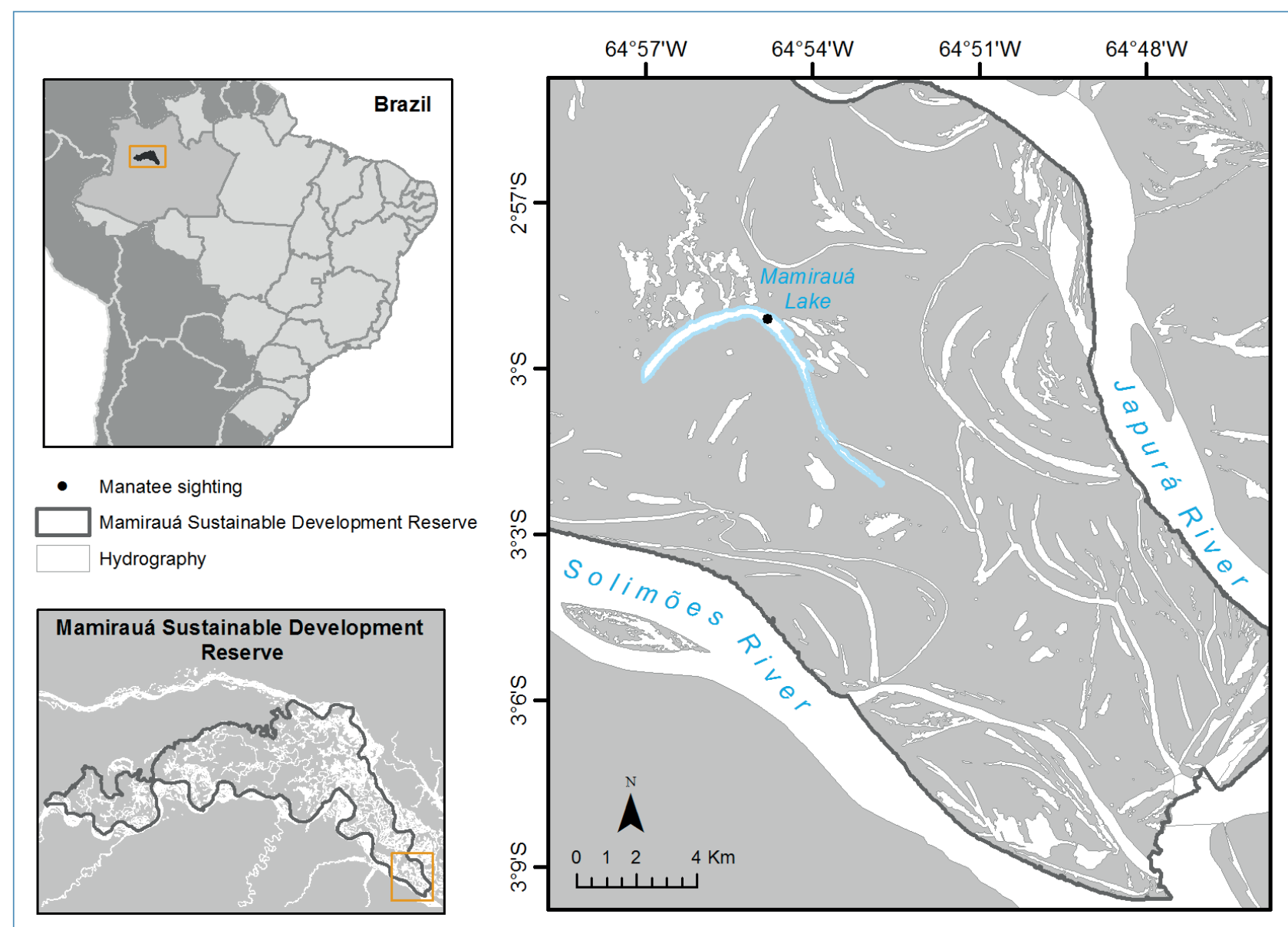

Figure 1. Mamirauá Lake and sighting site of manatee group.

Approximately one minute later the animals returned to the surface, $5 \mathrm{~m}$ away from where they had last been seen. The displacement seemed to have been initiated by the presumed female, recognized by her size, followed by the presumed males. As the presumed female broke the surface, we observed a water splash caused by her heavy breathing. The female's dorsum was again exposed and we could again observe a pectoral fin holding her. The female made small rotations with her body, and was noted breathing in a less discreet way while exposing her tail, with one of the presumed males' fin grasping her body. As the female rotated her body, part of a male's dorsum and head became exposed at the surface (Figure $3)$, until he submerged in a vertical position. The female remained submerging and approaching the surface at short intervals. Heavy breathing by the female was again noted. At one point estimated three presumed males emerged almost simultaneously to breathe next to the presumed female. New attempts to hug the presumed female from the posterior portion of the dorsum were made, but it was not possible to distinguish if they were done by the same animal during the whole event. Apparently, there was at least one juvenile male compounding the group, the smallest one.

Hartman (1979) and Moore (1956) also reported the body rotation behavior for Florida manatees in a pursuit occasion. The authors described a female rolling away and presenting her dorsum to the males. In the present event an attempt by the female to make short displacements was also observed, where she started moving towards a flooded forest area, where she remained surrounded by dense vegetation making male access to her side and dorsum difficult. At this point we ended our observations, because of the difficulty to enter the dense flooded forest; however, the event continued, according to the field base warden who saw the group moving away from that position hours later. Another female strategy to avoid harassment reported for Florida manatees is to move to shallow areas, where copulation would be impossible (Caldwell, 1972; Hartman, 1979; Reynolds, 1981). At the time of our observation the water level was high and this option was unavailable, but this behavior was previously reported for Amazonian manatees in the dry season by local dwellers.

During most of the observed event, the female appeared to display an evasive behavior, moving away from the presumed males, rotating her body and making abrupt movements on the surface. Abrupt movements to discourage or avoid males like tail slaps appear to be a sexual behavior shared by sirenians, also reported for Florida manatees and dugongs (Caldwell and Caldwell, 1972; Hartman, 1979; Reynolds, 1979; Preen, 1989). 


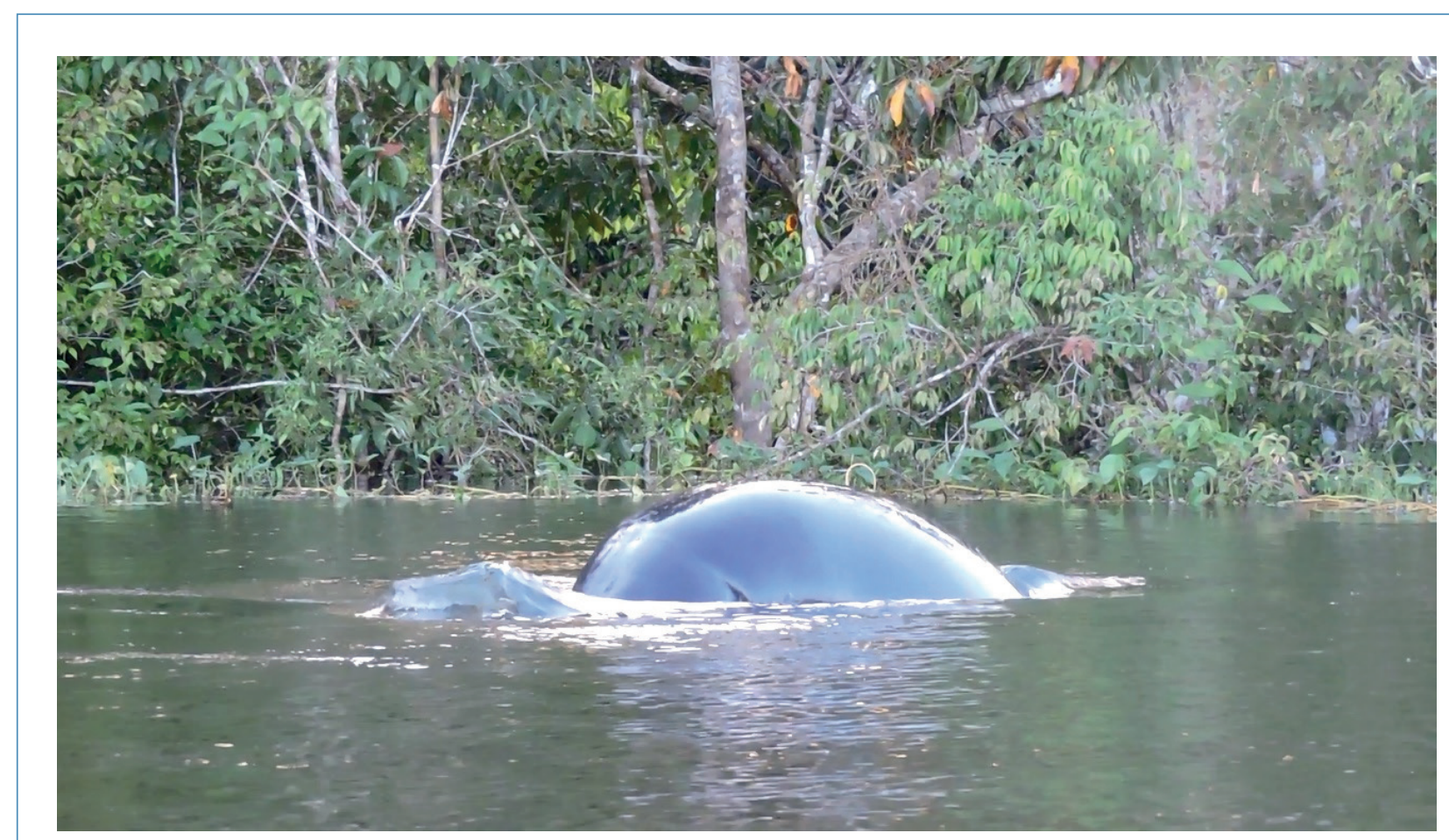

Figure 2. Presumed female showing evasive movements.

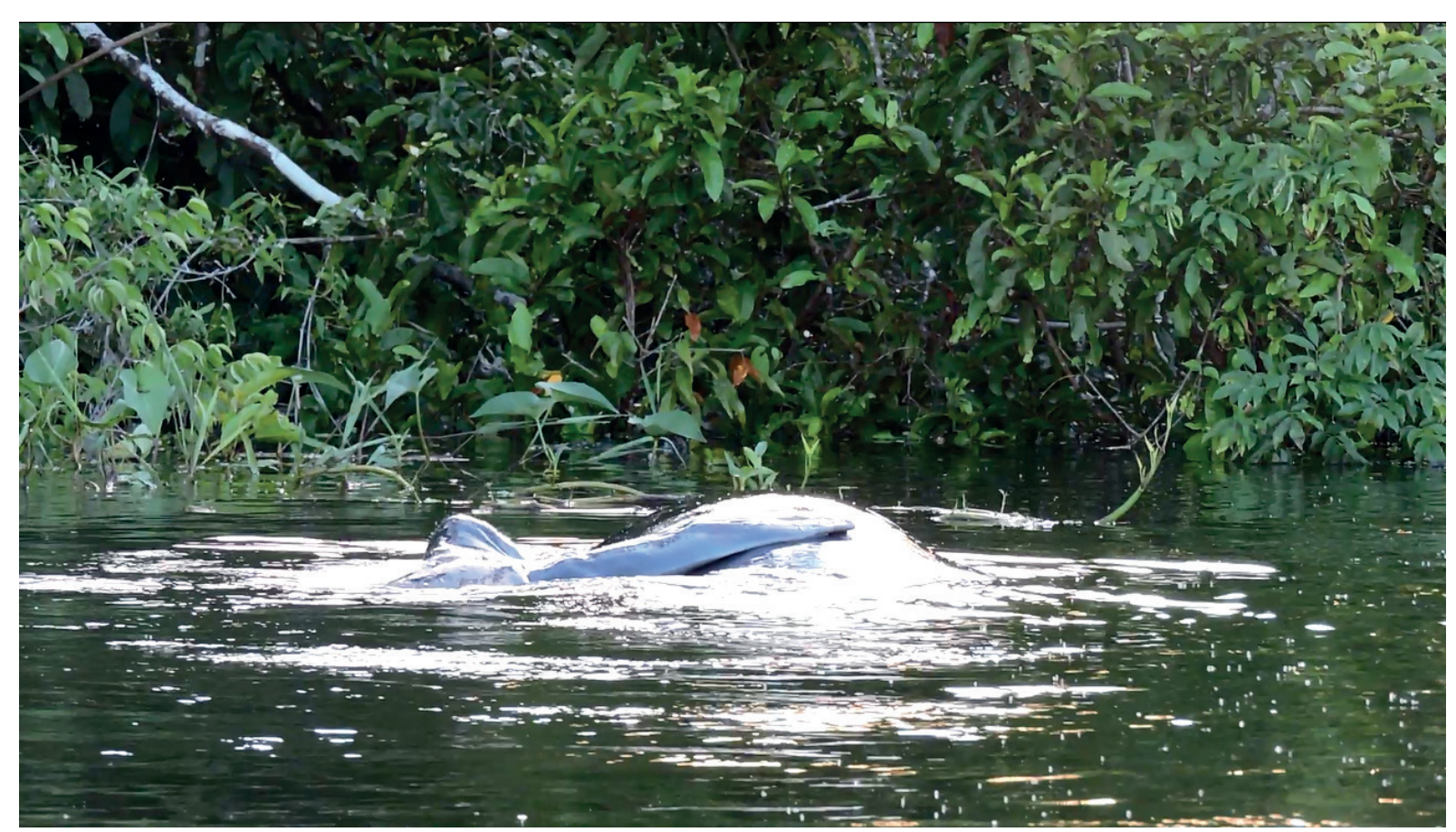

Figure 3. Presumed male hugging the presumed female and exposing its head.

In relation to the behavior of presumed males, we did not observe aggressive behaviors on the surface. Through detailed observations of reproductive behavior in Florida manatees, Hartman (1979) observed that competition among males for a position next to the receptive female appears to be the main form of aggression. In contrast, Reynolds (1981) states that males apparently do not compete for the female, but rather establish territories around her, each male attempting to remain as close as possible to the female in order to be the first one to copulate, and this may cause males to collide with each other. For dugongs, Preen (1989) reported behavior as more violent than manatees, because their tusks allow for more serious injuries. 

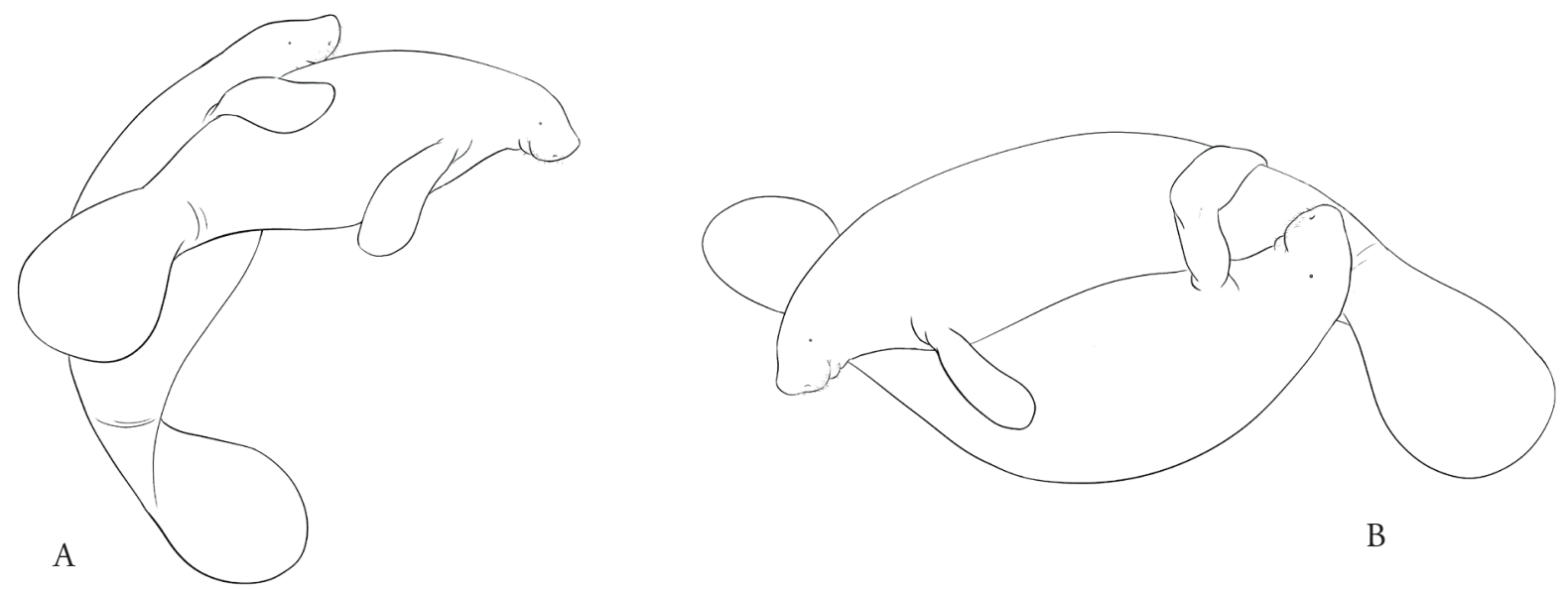

B

Figure 4. a) Probable position of the presumed male when his dorsum was exposed near to the presumed female.

b) Supposed underwater behavior of the presumed male when grasping the posterior portion of the female's body.

Drawings by Gabriel Melo-Santos.

Reports by local dwellers of Amazonian manatees describe that males may strongly hit the female on its venter with their caudal fins, in order to make her receptive, and hit other males in order to frighten them away, although this may have been an interpretation based on one or few observations and local knowledge. Pereira (1944) mentioned that, in some cases, the female may die during sexual aggregations. Based on interviews with local hunters in the Amanã Sustainable Development Reserve, Calvimontes (2009) also described reports of aggressive behaviors by males, which may lead to the death of the female, depending on the number of males pursuing her.

Our observations were limited by a series of factors. First, there was no visual gender confirmation of any individuals in the group, which would only be possible with exposure of the ventral surface. Second, the presumed female entered an area of difficult access for the observers in the middle of the flooded forest; at this point we did not observe the males, so we could not affirm they were still with her. Third, Lake Mamirauá waters are turbid, which hinders visualization of underwater behaviors and, therefore, we did not have enough information to complete the sequence of behaviors, observe if there was a repetitive sequence, or quantify the total duration of each of them. A schematic drawing of these supposed underwater behaviors can be observed in the Figure 4. Despite this, we observed that as with other sirenian species (Reynolds, 1979; Reynolds and Odell, 1991; Lima et al., 2005, Lazzarini et al., 2014) there does not seem to be one single posture assumed during copulation.

In Florida manatees it has been described that the receptive female will swim short distances, between copulations, before stopping and accepting new contact, so mating herds may persist for up to a month (Hartman, 1979; Bengtson, 1981; Rathbun et al., 1995), moving at a rate of up to $30 \mathrm{~km} /$ day and up to a total of $160 \mathrm{~km}$ (Bengtson, 1981). In this event, the group was not observed in the same area the next day, so the time that Amazonian manatees mating herds persist are still unknow.

Our estimate is that at least five animals were involved in this event. Previous information on Amazonian manatee size of reproductive groups was obtained through local ecological knowledge in Pereira (1944), who documented between 15 and 30 Amazonian manatees. Most recently, Calvimontes (2009) showed through interviews that mating events may have the participation of only two and up to 10 males per female. In Florida manatees, up to 22 males have been recorded in reproductive groups (Reynolds et al., 2009).

In this presumed reproductive group, we noted that among the presumed males some appeared to be smaller than the presumed female. In Florida manatees the composition and size of the mating groups vary, starting small and gathering more males over time, including immature ones (Bengtson et al., 1981; Rathbun et al., 1995). Hartman (1979) also described a reproductive group formed by a female, three adult males and two subadults. The author also noted that juvenile males approach and leave the herd often, while adult males tend to remain close to the female.

Homossexual behavior and other interactions that look like reproductive events (e.g. use of pectoral fins in social interactions) have been reported in sirenians (Hartman, 1979; Preen, 1989). However, we believe that our observations were part of an episode of reproductive behavior due to the repetitive interaction focused on only one of the animals (presumed female, the largest manatee that we observed), as described by Pereira (1944) for T. inunguis, Hartman (1979) for T. m. latirostris, and Anderson and Birtles (1978) and Preen (1989) for D. dugon. 
This is the first documented report of a potential event of mating herd in Trichechus inunguis. The Amazonian manatee is a species of extremely discreet behavior, and its observation in the wild is currently a rare event. Nevertheless, the animals involved in this interaction allowed an approximation which is not normally tolerated. The fact that the animals were so oblivious to observers evidences the vulnerability of this species of cryptic behavior during the reproductive period, especially in a region where hunting still persists.

\section{Acknowledgments}

This work was possible thanks to an invitation by the Research Group on Ecology and Conservation of Felids in Amazonia of Mamirauá Institute for Sustainable Development to join their group on field activities. We particularly thank Arilson Barbosa Lopes and Lázaro Pinto dos Santos for allerting us of the manatee group's activities and helping us to get closer with a canoe. We also thank all the reviewers and Guilherme Guerra for their valid suggestions and comments to the manuscript. We are indebted to Amanda Lelis, from Communications at Mamirauá, for photo editions and to Gabriel Melo-Santos for the drawings that contribute to the interpretation and visualization of manatee underwater behaviors.

\section{References}

Anderson, P.K. (2002) Habitat, niche, and evolution of sirenian mating systems. Journal of Mammalian Evolution 9 (1/2): 55-98.

Anderson, P.K. and Birtles, A. (1978) Behaviour and ecology of the dugong, Dugong dugon (Sirenia): Observations in Shoalwater and Cleveland Bays, Queensland. Australian Wildlife Research 5: 1-23.

Arraut, E.M., Marmontel, M., Mantovani, J.E., Novo, E.M.L.M., Macdonald, D.W. and Kenward, R.E. (2010) The lesser of two evils: seasonal migrations of Amazonian manatees in the Western Amazon. Journal of Zoology 280 (3): 247-256. https://doi.org/10.1111/j.1469-7998.2009.00655.x

Bengtson, J.L. (1981) Ecology of manatees (Trichechus manatus) in the St. Johns River, Florida. Ph.D. Thesis. University of Minnesota. Minneapolis, USA. 149 pp.

Best, R.C. (1982) Seasonal breeding in the Amazonian manatee, Trichechus inunguis (Mammalia: Sirenia). Biotropica 14(1): 76-78. https://doi.org/10.2307/2387708

Caldwell, M.C and Caldwell, D.K. (1972) Behavior of marine mammals. Pages 419-465 in Ridgway, S.H. (Ed.) Mammals of the Sea: Biology and medicine. Charles C. Thomas, Publisher, Springfield, VA. 812 pp.

Calvimontes, J. (2009) Etnoconocimiento, uso y conservación del manatí amazónico Trichechus inunguis en la Reserva de Desarrollo Sostenible Amanã, Brasil. M.Sc. Thesis. Universidad Nacional Agraria La Molina. Lima, Peru. 210 pp.
Frost, O.W. (Ed.) (1988) George Wilhem Steller - Journal of a voyage with Bering, 1741-1742. Stanford University Press, CA. 252 pp.

Hartman, D.S. (1979) Ecology and Behavior of the Manatee (Trichechus manatus) in Florida. Special Publication, American Society of Mammalogists 5: 1-153. https://doi. org/10.5962/bhl.title.39474

Lazzarini, S.M., Vergara-Parente, J.E. and Ribeiro, D.C. (2014) Sirenia (Peixe-boi-da-amazônia e Peixe-boi-marinho). Pages 936-972 in Cubas, Z.S., Silva, J.C.R. and Catão-Dias, J.L. (Eds) Tratado de Animais Selvagens. Ed. Roca, São Paulo.

Lima, R.P., Alvite, C.M.C., Vergara-Parente, J.E., Castro, D.F., Paszkiewicz, E. and Gonzalez, M. (2005) Reproductive behavior in a captive-released manatee (Trichechus manatus manatus) along the Northeastern Coast of Brazil and the life history of her first calf born in the wild. Aquatic Mammals 31(4): 420-426. https://doi.org/10.1578/am.31.4.2005.420

Moore, J.C. (1956) Observations of manatees in aggregations. American Museum Novitates 1811: 1-24.

Pereira, M.N. (1944) O peixe-boi da Amazônia. Boletim do Ministério da Agricultura (Rio de Janeiro) 33: 21-95.

Preen, A. (1989) Observations of mating behavior in dugongs (Dugong dugon). Marine Mammal Science 5(4): 382-387. https://doi.org/10.1111/j.1748-7692.1989.tb00350.x

Rathbun, G.B., Reid, J.P., Bonde, R.K. and Powell, J.A. (1995) Reproduction in free-ranging West Indian manatees (Trichechus manatus). Pages 135-156 in O'Shea, T.J., Ackerman, B.B. and Percival, H.F. (Eds) Population Biology of the Florida Manatee. U.S. Dept. of the Interior, Information and Technology Report 1. National Biological Service, Washington, D.C.

Reynolds, J.E. (1979) The semisocial manatee. Natural History 88(2): 44-52.

Reynolds, J.E. (1981) Aspects of the social behaviour and herd structure of a semi-isolated colony of West Indian manatees, Trichechus manatus. Mammalia 45(4): 431- 451. https://doi.org/10.1515/mamm.1981.45.4.431

Reynolds, J.E. and Odell, D.K. (1991) Manatees and Dugongs. Facts on File, Inc., New York. 192 pp.

Reynolds, J.E., Powell, J.A. and Taylor, C.R. (2009) Manatees (Trichechus manatus, T. senegalensis and T. inunguis). Pages 682-691 in Perrin, W.F., Würsig, B. and J.G.M. Thewissen (Eds) Encyclopedia of marine mammals. 2.ed. Academic Press, Amsterdam.

https://doi.org/10.1016/b978-0-12-373553-9.00159-0

Rodrigues Ferreira, A. (1903) Memória sobre o peixe-boy e o uso que lhe dão no Estado do Grão Pará. Arquivos do Museu Nacional XII: 169-174 [reprinted from the 1790 original, Viagem Filosófica pelas capitanias do Gráo Pará, Rio Negro, Mato Grosso e Cuiabá]. 